\title{
The Impact of Experienced and Expressed Emotion on Legal Factfinding
}

\author{
Jessica M. Salerno \\ Arizona State University
}

To cite this paper:

Salerno, J. M. (2021). The impact of experienced and expressed emotion on legal factfinding. Annual Review of Law and Social Science, 17. https://doi.org/10.1146/annurev-lawsocsci021721-072326

\begin{abstract}
Judges and jurors are asked to comb through horrific evidence of accidents and crimes when choosing verdicts and punishment. These factfinders are likely to experience and express intense emotions as a result. A review of social, cognitive, moral, and legal psychological science illuminates how experienced and expressed emotions in legal settings can unconsciously bias even the most well-intentioned, diligent factfinder's decision-making processes in prejudicial ways. Experiencing negative emotions creates motivation to blame and punish - instigating blame validation processes to justify guilty/liability verdicts and harsher punishments. The review also examines how emotion expression can impugn legal actors' credibility when it violates factfinders' (often unrealistic) expectations for appropriate emotion in legal contexts. It considers misguided and promising interventions to help factfinders regulate emotional responses, advocating limiting emotional evidence as much as possible and, when not possible, helping factfinders reframe how they think about it and remain aware of their potential biases.
\end{abstract}

\section{INTRODUCTION}

Law has traditionally been described as grounded in reason and devoid of emotion (Bandes 1999, Maroney 2011). Yet, people naturally feel moral emotions when they witness an act of harm to another person, which is an almost definitional aspect of a legal factfinder's job when judging a criminal or civil case. Broadly, moral emotions are emotional responses to moral violations, including "other-condemning" emotions like anger and disgust, or emotions that motivate moral behavior, including "other-suffering" emotions like sympathy and empathy- 
among others (Haidt, 2002). Thus, negative moral emotions commonly include those with a negative valence that focus on condemning immoral acts of others (i.e., anger, disgust, moral outrage) and positive moral emotions commonly include those with a positive valence focused on moral concern for others (i.e., sympathy, empathy, pity) (Giner-Sorolla, 2012). Judges and jurors are asked to delve into the most disturbing details of whether and why someone caused intentional or unintentional (and often violent) harm to another person. Not only are emotions inevitably and inextricably linked to cognition, but to some degree they are desirable. People with brain damage to areas necessary for social emotions exhibit abnormal and sometimes disturbing moral judgment of what is right and wrong (Koenigs et al. 2007). However, extremely emotional evidence at trial can heighten factfinders' moral emotions and stress to a problematic degree. Heightened moral emotions can directly prejudice factfinders against defendants by creating a need to blame and punish for the harm they have witnessed. More insidiously, heightened moral emotions can also unconsciously bias even the most well-meaning and diligent factfinder's decision-making process in ways that can prejudice them against defendants. In addition, victims', defendants', witnesses', and attorneys' emotional expressions can bias factfinders' judgments of their credibility when they violate factfinders' (often incorrect) expectations for what emotion they think is appropriate. Further, when factfinders themselves express their emotions, they can gain or lose influence, depending on their gender or race. Drawing from moral, legal, cognitive, and social psychological science, I review how factfinders' experienced and expressed emotion can lead to biases in legal decision making, as well as both misguided and promising interventions aimed at helping factfinders regulate their emotions.

\section{EMOTIONAL REACTIONS TO EVIDENCE AT TRIAL}

Emotionally disturbing evidence, such as gruesome crime-scene photographs, is extremely

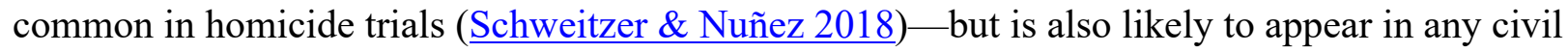
or criminal trial that involves violence or accidental injuries. With advancing technology, this is likely to include high-resolution photographs of gruesome injuries, video footage of horrific accidents and/or violent crimes, and even potentially Hollywood-level, animated reenactments of violence or accidents that give the air of evidence but do not in fact hold probative value. Jurors report exposure to graphic evidence and emotional testimony as common sources of stress 
(Lonergan et al. 2016), leading to vicarious trauma (Robertson et al. 2009). After serving jury duty, substantial percentages of jurors meet diagnostic criteria for post-traumatic stress disorder (Palmer 2005) and trauma-related symptoms including intrusive memories, insomnia, and nightmares (Lonergan et al. 2016). Jurors meet criteria for clinical depression more often when exposed to graphic evidence (Shuman et al. 1994). Judges also report vicarious trauma from being exposed to the details of horrific violent crimes (Chamberlain \& Miller 2008, Jaffe et al. 2003) and experience anger (Maroney 2012), sadness ( 2011) on the job. Not only are trials a recipe for intense moral emotions, but they officially assign factfinders as the arbiters of ensuring justice for the emotionally disturbing harms they witness.

Traditionally, being a good judge has meant remaining cold, unemotional, and impartial (Maroney \& Gross 2014). Indeed, both trial attorneys and federal judges believe that judges are less likely to be influenced by their emotional reactions than are jurors (Figure 1), rating judges below the midpoint but jurors above the midpoint. Psychological research demonstrating desensitization, or the decreased sensitivity and reactivity of typical emotional responses to events (Cline, Croft \& Courrier, 1973), in other contexts (Anderson et al. 2010) suggests that judges could develop blunted emotional reactions to disturbing evidence over the course of their careers. Unfortunately, very little empirical research compares judges' and jurors' emotional responses or how much they are affected by them. The psychological science I review on the impact of experiencing and expressing emotions on legal judgments is therefore largely based on lay samples. The lack of judicial research precludes me from being able to say whether it applies equally to judges and highlights the importance of future research on judges. 


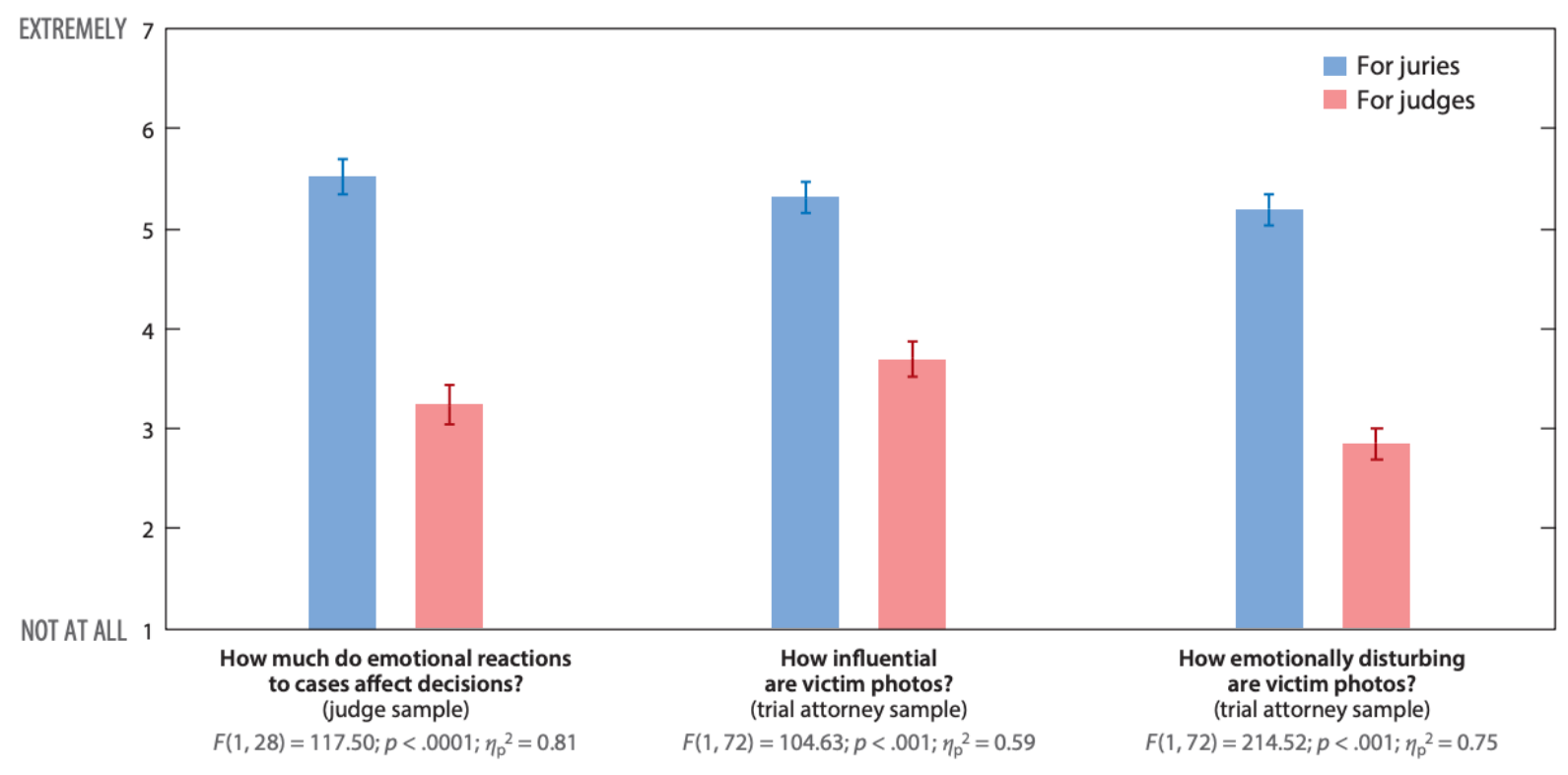

Figure 1

Judges' and trial attorneys' beliefs about how much juries versus judges are influenced by emotional reactions. These data are based on survey responses from judges $(N=29)$ and attorneys $(N=73)$ before they attended a variety of continuing legal education sessions conducted by the first author. The results in the figure are based on repeated-measures analysis of variance. Participants were asked each question twice: one in reference to juries' decisions and the other in reference to judges' decisions.

\section{EXPERIENCED EMOTION AND LEGAL FACTFINDING}

\section{The Effect of Emotion on Legal Judgments}

Jurors' emotional reactions are significantly related to their legal judgments (eigenson 2016).

Negative moral emotions like anger, disgust, and moral outrage, in particular, are correlated with more guilty and liability verdicts (Bright \& Goodman-Delahunty 2006, Matsuo \& Itoh 2017, Salerno 2017, Salerno \& Peter-Hagene 2013, Salerno \& Phalen 2019a) and harsher punishments (e.g., Georges et al. 2013, Nuñez et al. 2015). Positive moral emotions, such as sympathy or empathy for victims, are correlated with decreased convictions (Jones et al. 2020), whereas empathy for defendants can increase convictions (Archer et al. 1979, Haegerich \& Bottoms 2000.

Emotionally evocative evidence can elicit these moral emotions in jurors, which are, in turn, associated with harsher verdicts and punishment. These experiments most commonly test the impact of gruesome photographs of victims and victim impact statements (VIS) from victims or their families (Bandes \& Salerno 2014, Phalen et al. 2020, Salerno \& Bottoms 2009). When mock jurors are randomly assigned to view gruesome photographs of victims' injuries, they render verdicts more in line with blaming the defendant and harsher punishments, compared with 
those who learn about the details of the injuries through verbal testimony (Grady et al. 2018). More specifically, gruesome photographs increase guilty verdicts (Bright \& Goodman-Delahunty 2006, Edwards \& Mottarella 2014, Matsuo \& Itoh 2017, Salerno 2017), liability verdicts (Bright $\underline{\text { \& Goodman-Delahunty 2011, }}$ Oliver \& Griffitt 1976), harsher sentences (Finkelstein \& Bastounis 2010), and damage awards (Oliver \& Griffitt 1976, Whalen \& Blanchard 1982).

Several studies have identified jurors' emotional reactions to the photographs as an explanation (or mediator) of the effect. Mock jurors who saw gruesome photographs were significantly more likely to vote guilty via increased disgust (Salerno 2017) and anger (Bright \& Goodman-Delahunty 2006). Similarly, a gruesome photograph of a plaintiff's severed leg significantly increased liability verdicts via increased disgust (Salerno \& Phalen 2019a). Seeing a combination of photographs of the victim alive and well before she died and gruesome postmortem photographs after she died is particularly potent. Mock jurors are even more conviction prone when they see this combination compared with just postmortem photographs, because seeing the contrast increases anger and sadness in addition to the disgust elicited by the postmortem photographs (M. Adamoli, H.J. Phalen, \& J.M. Salerno, manuscript in preparation).

Victim impact statement (VIS) studies provide converging evidence that emotional responses to evidence can lead to harsher judgments. Mock jurors exposed to VIS recommended harsher sentences than those who were not exposed (Bandes \& Salerno 2014, Phalen et al. 2020). At least one study identified emotional reactions as the explanation: Mock jurors who saw VIS were more likely to recommend the death penalty than those who did not see VIS, because such statements increased sympathy/empathy toward the victim (Paternoster \& Deise 2011).

Beyond gruesome photographs and VIS, experiments have identified emotional reactions as an explanation for the impact of many other factors that make mock jurors choose harsher verdicts and punishments. Examples include mock jurors $(a)$ punishing gay offenders more, because they elicit more moral outrage relative to heterosexual offenders (Salerno et al. 2014); (b) voting liable more when civil sexual assault defendants were male, because they elicited more moral outrage than female defendants (McCracken \& Stevenson 2017); (c) voting guilty less when a gay panic defense was offered, because they felt less moral outrage than when they did not hear a gay panic defense (in the case of conservative jurors) (Salerno et al. 2015); and (d) voting guilty more when they saw irrelevant negative emotional pretrial publicity about the defendant, because it made them angrier than jurors who did not see it (Ruva et al. 2011). 


\section{Probative Versus Prejudicial?}

The fact that emotionally disturbing evidence like crime-scene photographs or VIS affects factfinders' judgments is probably not surprising to attorneys or judges. Nor would it be concerning unless it was clear that it was affecting jurors' judgments through improper or extralegal channels. If emotional evidence affects decisions because of the information it provides, fine. If emotional evidence affects decisions because of factfinders' emotional reactions, we must scrutinize when that emotion might be probative, and when that emotion prejudices them against defendants (Bandes \& Salerno, 2014), which is more problematic. The legal system recognizes the potentially prejudicial impact of emotionally disturbing evidence. Rule 403 dictates that judges can exclude relevant evidence if its prejudicial impact outweighs its probative value, clarifying in the advisory notes that prejudice "means an undue tendency to suggest a decision on an improper basis, commonly, though not necessarily, an emotional one”. This would be an incredibly difficult assessment even for emotion researchers, let alone for a judge with no psychological training. She must somehow quantify the probative value of, for example, a given photograph (taking into account redundant evidence that establishes the same information), play armchair psychologist and anticipate how the photograph might prejudice decision making, and weigh the two against each other.

Emotion is not monolithically prejudicial or probative. Instead, determining whether an emotional response is probative or prejudicial is incredibly complex and case-specific. Although there is certainly a lot of empirical evidence (that will be reviewed in detail) that emotion can prejudice legal factfinders' decision making processes, emotion also has potential to be probative in some circumstances. In United States v. Old Chief, the Supreme Court recognized the prosecution's right to "tell a colorful story with descriptive richness," and some argue that stripping evidence of its emotional impact would mean stripping it of its persuasive, and therefore, probative power. For example, people who endorse a retribution-based philosophy of punishment argue that emotional reactions to harm are probative to punishment decisions — and in fact, in the death penalty context, it is made explicit that jurors should consult their emotions. Some consider moral outrage to be an emotional barometer that reflects how much harm has been committed, which determines how much punishment is appropriate (Bastian et al. 2013, $\underline{\text { Carlsmith et al. 2002, Lotz et al. 2011, Okimoto \& Brescoll 2010, }}$ Salerno \& Peter-Hagene 2013). Thus, factfinders' emotional reactions to harm depicted in gruesome photographs or VIS 
might provide probative information regarding how much punishment a guilty defendant deserves. Factfinders' moral outrage or sympathy/empathy about plaintiffs' pain or grief might be probative for quantifying pain-and-suffering damages. In some cases, jurors' emotional responses might also be probative for verdicts. For example, in self-defense cases, jurors' empathetic fear might inform whether they believe the defendant felt imminent danger, or jurors' anger when hearing evidence of provocation might inform whether they think the defendant's loss of control was reasonable.

Yet, there are also many circumstances in which jurors' emotional reactions to emotional evidence might be prejudicial in that their emotional responses can bias their decision making processes, while providing little probative value beyond what is already conveyed via other evidence. Take an example of jurors who are shown gruesome photographs of injuries while making a verdict determination about whether the evidence that a murder defendant committed the act in question is strong enough to meet the burden of proof. Their emotional reaction to seeing graphic depictions of harm or suffering (that might be probative for punishment judgments) would not be probative for a guilt determination. Yet, their emotional reaction could instigate a biased review of the evidence in a way to support voting guilty, to satisfy their emotional need to see someone punished for the harm they witnessed. If the photographs' probative information about the injuries can be established in verbal testimony or in a less emotionally evocative medium, this prejudicial impact might outweigh its probative value.

Thus, it is very important for not only judges but also researchers designing experiments to consider what specific legal judgment is being made when determining whether an emotional response is probative or prejudicial. Susan Bandes and I developed a nuanced framework for how to think about whether a given piece of evidence is probative or prejudicial in a given case, based on questioning what probative information the evidence is meant to convey, how the specific emotions elicited by the evidence will affect their decision making about the evidence, and whether those effects of emotion help or hurt the jurors' deliberative process (Bandes \& Salerno, 2014). The goal of this article is to review psychological science that will help inform these questions.

One way that research psychologists can help inform judges' admissibility decisions is by determining the specifically prejudicial impact of evidence that heightens jurors' emotions on their decision-making process, which judges can weigh against the evidence's probative value. 
Most well-designed experiments, for example, hold the information mock jurors get constant across conditions, making sure that mock jurors in the no-photograph control condition hear about the victim's injuries via verbal testimony. This aims to isolate the emotional impact of seeing the photograph above and beyond learning the information it contains. As further evidence that the impact of gruesome photographs can operate through emotional (rather than probative) channels, mock jurors who saw gruesome photographs in color were more likely to vote guilty than those who got virtually the same information from the same photographs in black-and-white, because color photographs elicited more disgust (Salerno 2017). Further, the gruesome-photograph effect was limited to mock jurors who were chronically more aware of their bodily sensations and therefore were more aware of their emotional reaction to the

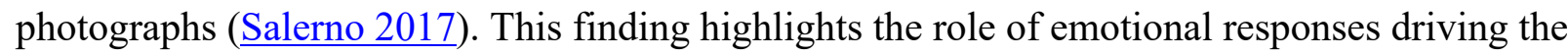
gruesome-photograph effect; if the effect were driven purely by learning probative information from the photographs, the degree to which mock jurors tend to be aware of their emotional responses should not have mattered.

\section{Potentially Prejudicial Effects of Emotional Reactions on Decision-Making Processes}

This has been a discussion of whether factfinders' emotional reactions in and of themselves are probative. A judge must also consider, however, how jurors' emotional reactions to evidence might influence how they review other evidence and reach their decision in prejudicial ways, which I review next. Figure 2 offers a visual model of how moral emotions (i.e., anger, disgust, moral outrage, sympathy/empathy) affect the various psychological processes involved in legal decision making. The figure summarizes psychological research demonstrating that emotional evidence that elicits moral emotions can create a need to blame and punish, which can make factfinders more likely to render pro-prosecution/plaintiff judgments directly and indirectly. The indirect effect of emotional evidence on judgments operates through blame validation processes, which can bias even the most diligent juror's decision-making process by filtering their review of the evidence through a prosecutorial mindset. More specifically, heightening jurors' negative moral emotions can increase blame validation processes that include making them $(a)$ skew how they process evidence to pay attention to and rely on prosecution/plaintiff evidence more and defense evidence less, $(b)$ perceive more intentionality, $(c)$ lower their burden of proof for ruling against the defendant, and $(d)$ perceive the same action as more morally wrong, all of which predict greater likelihood of ruling against the defendant and recommending harsher 
punishments. The model also describes other impacts of negative emotions on decision making in general, including reliance on heuristics and stereotypes, as well as memory. Finally, it describes factors that might lead to factfinders having selective emotional responses based on who the legal actors in the case are, such as the legal actors' status, race, or similarity to the factfinder. Next, I will review the relevant psychological science that supports and explains each aspect of the model.

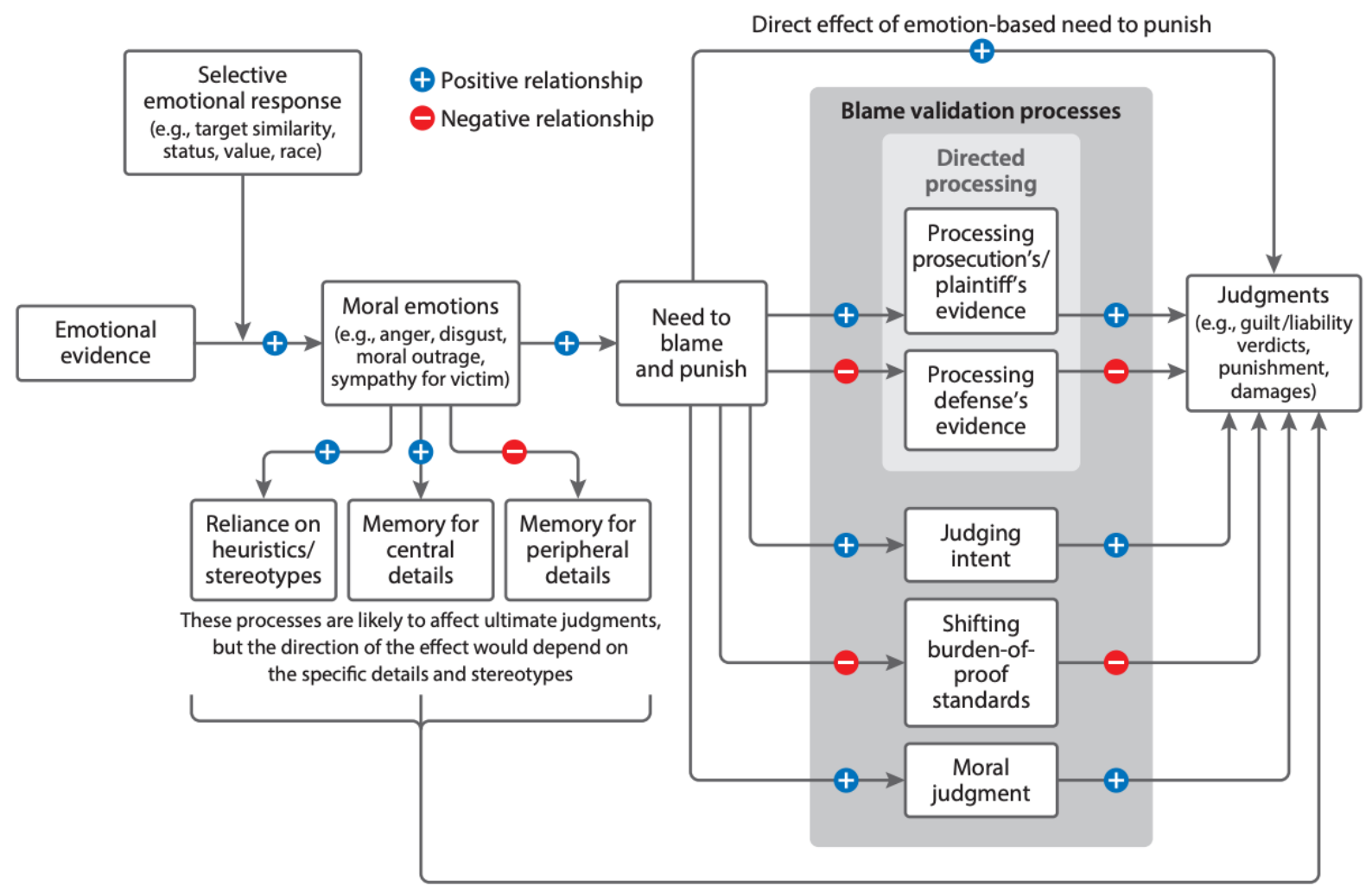

Figure 2

Visual model of how moral emotional reactions to emotional evidence affect psychological processes involved in legal decision making.

\section{Emotion increases the need to blame and punish.}

Rousing negative emotion can directly motivate factfinders to make more pro-prosecution/plaintiff judgments (Feigenson 2016, Feigenson \& Park 2006, Salerno \& Bottoms 2009). Feeling moral emotions like anger, disgust, and moral outrage can create a need to blame and punish (Horberg et al. 2009, Lerner et al. 1998, Salerno \& Peter-Hagene 2013) that might directly motivate harsher verdicts and punishment. For example, people who have been put in an angry mindset are more likely to blame targets, compared to sad or neutral participants who read about the same transgression (Keltner et al. 1993). People often rely on their feelings as information 
(i.e., the affect-as-information heuristic), which can open the door to jurors' emotion stemming from one thing being misdirected or "misattributed" (Schwarz \& Clore 1983) to another. Unfortunately, emotions are messy and difficult to compartmentalize. It is not realistic to expect factfinders to keep the impact of their emotional reactions to horrific crimes limited to punishment judgments, for example, and to avoid letting them bleed into guilt judgments about whether there is enough evidence to blame the defendant for the crime. For example, mock jurors' anger and disgust while reviewing evidence was associated with moral outrage and a need to punish, which were also related to more guilty verdicts (Salerno \& Peter-Hagene 2013). Further, gruesome photographs increased convictions via disgust only among those who had moderate-to-high awareness of the feelings in their body (Salerno 2017). The fact that mock jurors who were unaware of their bodily sensations were unaffected by gruesome photographs suggests that the photographs' impact was driven by mock jurors' emotional reactions influencing their verdicts. If the photographs' impact was probative, the degree to which mock jurors were aware of their emotional reactions would not have made a difference.

\section{Selective emotional response.}

Thus, emotion can be a powerful persuasion tool-but emotion is not felt equally for all targets. People feel moral emotions more for those who are similar to themselves (i.e., in their ingroup), valued by society, and of higher status (Bloom 2006). Feelings like anger, empathy, or sympathy work like a spotlight, directing our attention and concern toward those who elicit these emotions (Bloom 2006). We have already reviewed examples of how attorneys might achieve favorable verdicts and punishments by eliciting jurors' emotions on behalf of their client. However, factfinders will generate those moral emotions less for those who are different from themselves (Loewenstein \& Small 2007) or of lower status (Bloom 2006).

Indeed, people tend to blame perpetrators of lower societal virtue (e.g., a drug-dealing highschool dropout) more than higher-status perpetrators (e.g., a straight-A, honor-roll student) who committed the same act (Nadler 2012, Nadler \& McDonnell 2012) — perhaps because they are more difficult to sympathize/empathize with. VIS have more impact when describing high-status

victims relative to low-status victims (Greene, Koehring, \& Quiat, 1998). People are also more likely to summon anger and take action on behalf of someone they categorize as in their ingroup than on behalf of dissimilar or outgroup members (Yzerbyt et al. 2003). For example, we have found preliminary evidence that among White participants, gruesome photographs of White 
murder victims increased anger and disgust and, in turn, convictions. However, when the victim was Black, gruesome photographs did not increase anger, disgust, or convictions - even when the photographs depicted the same victim with lighter versus darker skin tone (J.M. Salerno, J. Nadler \& B. Bailey, manuscript in preparation). Thus, in line with criticisms of a downside of moral emotions being selectively applied to similar or valued others, these experiments suggest that heightening jurors' moral emotions might exacerbate the impact of biases against lowerstatus victims and defendants in the legal system.

\section{Moral emotion instigates blame validating processes in legal factfinding.}

Even the most diligent jurors putting great effort into evaluating the evidence carefully can have that process unconsciously tainted or biased by their moral emotions. Moral emotional reactions to harm create a need to blame and punish someone for that harm. Unfortunately, this need to see someone punished might impede factfinders' ability to assess the evidence effectively and impartially and convict the correct someone - not because they do not care about finding the right person, and not out of laziness, but because that motivation to find a culprit and see them punished might unconsciously instigate "blame validating processes" when reviewing the evidence (Alicke 2000). That is, strong negative emotional reactions to seeing someone harmed instigate blame validation processes, which unconsciously motivate people to look for evidence to justify blaming someone. Blame validation processes include many different cognitive biases or distortions that can color how jurors process and interpret evidence-from what they pay attention to, to how they judge intent. Some psychologists characterize this as negative emotion shifting people from "intuitive scientists," engaging in a balanced and impartial review of evidence, to "intuitive prosecutors," lowering their threshold for perceiving injustices and looking for information to support blaming and punishing someone for the harm (Goldberg et al. 1999). Next, I review psychological science regarding how emotion can affect a variety of cognitive processes involved in legal decision making. This review largely supports the theory that negative emotion instigates blame validation processing in prejudicial ways.

\section{Evidence processing.}

Experiencing negative emotions can influence how deeply jurors process evidence-but this is likely to depend on the specific emotion. Some negative emotions are associated with greater confidence in one's own opinion and less uncertainty, such as anger and disgust ( $\underline{\text { Smith \& }}$ 
Ellsworth 1985, Tiedens \& Linton 2001), which can lead to more shallow processing overall and greater reliance on cognitive shortcuts, heuristics, and stereotypes (Tiedens \& Linton 2001). For example, mock jurors' anger was negatively related to the number of inconsistencies they were able to detect in trial evidence (Semmler \& Brewer 2002), suggesting that anger might decrease processing and make jurors less vigilant about spotting inconsistencies in evidence. This is often due to being in an angry mindset, even if the source of anger is irrelevant to the decision. For example, recalling an angry memory before judging a legal case made mock jurors more likely to vote guilty for a Hispanic defendant than a White defendant, holding the case evidence constant. This was evidence of reliance on a racial stereotype that did not manifest in mock jurors who recalled a neutral or sad memory (Bodenhausen et al. 1994), which constitutes relying on not just an irrelevant, but prohibited, piece of information: race and ethnicity. When judging a euthanasia case of clear legal guilt, mock jurors randomly assigned to recall an angry memory beforehand were more likely to rely on their preexisting positive attitudes about euthanasia and nullify the law by acquitting the defendant; however, preexisting euthanasia attitudes were unrelated to verdicts among mock jurors who recalled a neutral memory (Peter-Hagene \& Bottoms 2017). These findings again highlight the complexity and myriad effects anger can have. In these studies anger did not simply make all mock jurors more conviction-prone overall, but instead made them more likely to rely on cognitive shortcuts - race in one case, and positive preexisting attitudes toward euthanasia in another.

There is also evidence, however, that experiencing negative emotions might decrease processing of some evidence more than other evidence (i.e., directed or motivated processing). Basic social psychological research demonstrates that when people feel negative emotion, they tend to process information that is consistent with that emotion more than inconsistent information (Forgas 1995). People feeling negative emotion are also more likely to process information consistent with blaming someone for what caused the negative emotion and to ignore information that contradicts blaming someone (Alicke 2000). This suggests that jurors feeling heightened anger and/or disgust about harm to a victim might be more likely to pay attention to and recall prosecution evidence and less likely to pay attention to and recall defense evidence, which in turn could make them more conviction prone.

In support, people who are experiencing heightened anger or moral outrage are more likely to ignore exculpatory circumstances (Gazzo Castañeda \& Knauff 2016) and mitigating factors for 
punishment (Georges et al. 2013), and to place greater importance on aggravating evidence, which makes them more likely to vote for a death sentence (Nuñez et al. 2015). Viewing disgustinducing gruesome photographs of a victim made mock jurors' verdicts less sensitive and less open to a strong defense (alerno 2017). Further, viewing disgusting photographs of victims' injuries can affect how mock jurors evaluate evidence completely unrelated to the information in the photographs (i.e., the victim's injuries). For example, mock jurors who saw gruesome photographs of a victim agreed more with prosecution evidence and less with defense evidence that was completely unrelated to the victim's injuries (e.g., a locksmith's testimony), which was associated with increased convictions (J.M. Salerno, H.J. Phalen, J. Nadler, N.J. Schweitzer \& S.A. Bandes, manuscript in preparation. Another study found evidence for similar patterns in civil trials (Salerno \& Phalen 2019a). These findings are also in line with coherence-based models of reasoning, which highlight the psychological need to achieve coherence when reasoning and demonstrate that activating emotion (even when unrelated to the judgment) can motivate people to pull their interpretation of case facts and verdicts in line with that emotion

(Simon et al. 2015). Thus, consistent with blame validation processing, heightening jurors' moral emotions can motivate them to process prosecution/plaintiff evidence more (by paying more attention to it and/or giving it more weight) and defense evidence less to justify harsher verdicts and punishments.

\section{Judging intent.}

Sometimes factfinders know the defendant committed the act but must judge the defendant's intent (e.g., provocation or insanity defenses, determining premeditation). Intense emotional reactions to harm create a need to blame. One way people justify blame is by perceiving more intent, foreseeability, and causation in the target's actions (Alicke 2000, Nadler 2012). For example, the anger that people felt about a defendant who caused a ski accident and was described as having bad moral character led them to perceive him as being more responsible for the accident relative to a defendant who caused the same accident but was described as having good moral character; they also judged him as having more intent and as having played more of a causal role (Nadler 2012). This can occur even when anger is completely unrelated to the judgment: Mock jurors randomly assigned to watch anger-inducing film clips later judged a civil defendant's actions as more intentional and recommended larger damage awards, relative to those who judged the same case but watched a neutral video beforehand (Lerner et al. 1998). 
Mock jurors who imagined anger-inducing events and then participated in an ostensibly unrelated second mock jury study judged a defendant's behavior to be more intentional and suggested harsher punishment than those who read the same evidence but imagined sad or neutral events beforehand (Ask \& Pina 2011). Anger also makes people attribute harmful outcomes more to individuals than to situational or external causes (Keltner et al. 1993). Thus, heightening negative emotions might motivate factfinders to see intent and thereby, for example, be more accepting of premeditation and less accepting of provocation or insanity defenses. In summary, consistent with blame validation processing, heightening jurors' negative moral emotions can motivate them to see more intent in a given action to justify harsher verdicts and punishments.

\section{Moral judgment.}

Exposing jurors to emotional evidence can also change how they judge the morality or wrongness of an act. When people are disgusted, they tend to judge the same actions as more morally wrong, severe (Chapman \& Anderson 2013), and harmful, which leads to greater moral condemnation (Schein et al. 2016) and punishment (Horberg et al. 2009) relative to those who are experiencing less disgust. This can happen even when the disgust is not relevant to the decision: Participants randomly assigned to feel disgust elicited by unrelated stimuli (i.e., being hypnotized, smelling a bad smell, recalling a disgusting event, watching a disgusting video, being in a disgusting room) rated moral transgressions to be more severe and wrong than if they did not feel irrelevant disgust (Schnall et al. 2008, Wheatley \& Haidt 2005). Of note, this disgust effect was strongest among participants who tended to be chronically aware of their bodily sensations ( $\underline{\text { Schnall et al. 2008) }}$. Thus, consistent with blame validation processing, heightening jurors' negative moral emotions can motivate them to see more moral wrongness in a given action to justify harsher verdicts and punishments.

\section{Shifting burden-of-proof standards.}

When feeling heightened emotions that create a need to blame and punish, mock jurors might unconsciously shift their burden of proof and require less evidence to vote guilty or find the defendant liable. When people are randomly assigned to feel anger, they tend to set lower thresholds for attributing intent for a transgression, which in turn predicts greater blame and punishment (Goldberg et al. 1999). Viewing an emotionally disturbing crime scene video led 
mock jurors to lower their burden-of-proof conviction standards relative to those who did not see the video (Kassin \& Garfield 1991). More specifically, they responded to the statement "The defendant should be found guilty if there is at least a _ \% chance that he committed the crime" with mock jurors who saw the emotional evidence reporting lower percentages $(76 \%)$ than did mock jurors who did not see the video (93\%). Thus, consistent with blame validation processing, heightening jurors' negative moral emotions can motivate them to lower their burden of proof to justify harsher verdicts and punishments.

\section{Attention and memory.}

Evidence that packs an emotional punch is desirable - attorneys often assume that more vivid and emotionally charged evidence will draw jurors' attention, engage them, and make the evidence more memorable. After all, one of the functions of emotion is to draw our attention to what is important and motivate us to deal with those important stimuli. Research outside legal settings shows that more emotionally evocative stimuli attract and hold people's attention longer (Ochsner \& Phelps 2007), and people remember emotional pictures more than neutral pictures (Canli et al. 2000). People pay more attention to statistics when they are imbued with emotion or a compelling narrative (Slovic 2010).

However, the potential for emotion to improve attention and memory has many important qualifiers. First, although memories for emotional events are often vivid and retained for a long time, they are not necessarily accurate (Kaplan et al. 2016). Second, emotion narrows attention, which can result in better memory for some things but worse memory for others. Reviews of laboratory and forensic field studies revealed that emotionally evocative stimuli make memory for the gist or central details of the stimuli better than less emotional stimuli (e.g., memory for a weapon) - but also degrade memory for peripheral, but important, details (e.g., the shooter's face) (Kaplan et al. 2016; Reisberg \& Heuer 2004, 2007). For example, viewing disgust-inducing photographs narrows attention relative to neutral photographs (Gable \& Harmon-Jones 2010), which could impair memory. People who saw arousing photographs remembered central details better, but those who saw negative photographs had more false memories about peripheral details than those who saw positive or neutral photographs (Van Damme \& Smets 2014). The authors suggest that jurors who are exposed to emotionally disturbing evidence might be particularly likely to remember the "central, threatening" details but might have poorer memory for peripheral, yet forensically important, details relevant to determining guilt (Van Damme \& 
Smets 2014). Thus, these studies suggest that viewing disturbing evidence might increase jurors' memory for the central details (e.g., the injuries) but might degrade their memory for important peripheral factors, such as other aspects of the crime scene or the testimony and interpretation that the expert is offering while presenting the photographs. Third, for some viewers, the emotional content might cause stress, which impairs hippocampal functioning, and therefore interferes with memory for structural, temporal, and sensory details (Payne et al. 2004, Reisberg

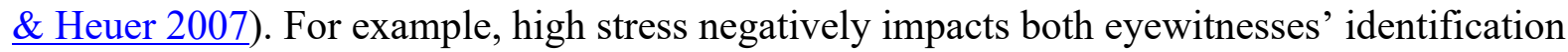
accuracy and memory for crime-related details (Deffenbacher et al. 2004).

In summary, if jurors do not have a stress response to emotional evidence, that evidence might help their memory for central details, while hurting their memory for peripheral, yet important, details. However, if the emotional evidence causes stress (which my review above suggests is common), jurors' memory will suffer overall.

\section{Interventions to Reduce the Prejudicial Impact of Emotions on Factfinding}

Emotion regulation refers to processes that determine which and when people experience and express emotions (Gross 1998). This literature provides a useful theoretical framework to suggest effective strategies to help judges (Maroney \& Gross 2014) and jurors regulate their emotional responses to evidence. Telling factfinders to suppress their emotional response to disturbing evidence is perhaps the most intuitive and common strategy. However, it is ineffective, can backfire by intensifying emotions (Gross \& Levenson 1993, Wegner 2009), and can deplete cognitive resources and hurt memory for evidence (Engelken \& Peter-Hagene 2020, Maroney \& Gross 2014). Indeed, jury instructions to disregard emotional testimony have been ineffective (Matsuo \& Itoh 2017) or even amplified its impact (Edwards \& Bryan 1997).

More effective strategies include avoiding situations that heighten emotions (Maroney \& Gross 2014), which would be difficult for judges given their role as evidence gatekeepers. It is more feasible, however, for jurors. As reviewed, relaying information about victims' injuries in less emotionally evocative ways (e.g., verbal testimony, black-and-white photographs) can reduce convictions relative to seeing disgust-inducing color photographs (Grady et al. 2018, Salerno 2017). Thus, limiting the amount and intensity of emotionally disturbing evidence and presenting it in less disturbing ways are crucial - especially if the defense has stipulated to the information or if the evidence is redundant with other, less disturbing, evidence.

If factfinders cannot avoid the emotional evidence, changing how they think about it can help 
regulate their emotional response (Gross \& Thompson 2007, Maroney \& Gross 2014). Further, research has demonstrated that one must be aware of one's bias to change it (Devine et al. 2012). In line with these findings, my collaborators and I designed jury instructions to make mock jurors aware of the potentially biasing influence of their emotional response to photographs of the deceased. Viewing gruesome photographs increased convictions when accompanied by standard jury instructions, but instructions that called mock jurors' attention to the ways that the photographs might bias them eliminated that increase (J.M. Salerno, H.J. Phalen, J. Nadler, N.J. Schweitzer \& S.A. Bandes, manuscript in preparation).

\section{Experienced Emotion Summary}

Emotionally disturbing evidence is common in trials and leads judges and jurors to report intense emotional reactions and stress, with substantial percentages reaching clinical levels. Emotional evidence, such as gruesome photographs of victims or VIS, elicit moral emotions - particularly anger, disgust, moral outrage, and sympathy/empathy. Although seeing evidence of extreme harm might sometimes have probative value, judges must weigh this against the many potential prejudicial effects of factfinders' moral emotional reactions on decision making. These moral emotions create a need to blame and punish someone for the harm the factfinders witnessed, which can directly make them more likely to render harsher verdicts and punishment. Problematically, those moral emotions are more likely to be elicited on behalf of more valued victims and defendants; thus, emotionally charged evidence might exacerbate discrepant legal judgments for high- versus low-status victims or defendants. Further, negative emotions can bias even the most well-meaning and diligent juror's decision-making process by putting them in a prosecutorial mindset and instigating blame validation processes, which justify blaming and punishing the defendant more harshly. More specifically, in line with blame validation processes, heightening jurors' anger and disgust can motivate them to $(a)$ process evidence less deeply and rely more on heuristics and stereotypes, $(b)$ process prosecution/plaintiff evidence more and defense evidence less, $(c)$ perceive more intent from the same actions, $(d)$ perceive the same action as more morally wrong and worthy of condemnation, and $(e)$ lower their burden of proof for ruling against the defendant, all of which predict greater likelihood of ruling against the defendant and recommending harsher punishments. Emotional evidence might improve details for central factors but degrade memory for important peripheral details - and to the degree that factfinders feel stress from the emotional evidence, memory will be impaired overall. 
Interventions based on telling factfinders to suppress their emotional responses are likely to be ineffective or backfire. Interventions based on limiting emotionally disturbing evidence or, when that is not possible, encouraging factfinders to reframe how they think about it and be aware of their potential biases hold promise for reducing the negative biasing impact of moral emotion.

\section{EXPRESSED EMOTION AND LEGAL FACTFINDING}

Legal proceedings run on persuasion and social influence. Attorneys, witnesses, victims, and defendants try to persuade factfinders. Jurors tasked with unanimity must persuade one another. Judges write opinions to justify their decisions. What happens when legal actors express the intense emotions they inevitably feel? Social functional theories of emotion explain how people draw inferences about others from the emotion that they express (Hareli \& Hess 2010, Keltner \& Haidt 1999, Van Kleef 2009, Van Kleef et al. 2011), which determine their impressions of that person and their behavior. Importantly, the inferences people draw from expressed emotion depend on their expectations for what is appropriate for the specific context (Van Kleef et al. 2011) —including how appropriate they think a lack of emotion is (Warner \& Shields 2009). People are suspicious of those who violate their expectations (Bond et al. 1993). Emotion expectations, and therefore the consequences of violating them, are likely to differ based on the expresser's role in the legal setting (defendant, victim, witness, attorney, juror), as well as their gender and race.

\section{Defendants}

Whether defendants express emotion can have a drastic impact on their fate. If defendants lack emotion, factfinders infer a lack of remorse and deliver harsher sentences as a result (Bandes 2016, Heath 2009, Sundby 1998, Ward 2006). Not showing remorse in court was one of the most frequent reasons jurors gave for choosing a death sentence (Haney et al. 1994, Sundby 1998). Experiments reveal that mock jurors perceive sad or remorseful defendants more positively than unemotional defendants (Tallon et al. 2015, Tsoudis \& Smith-Lovin 1998), and they are less likely to vote guilty even after deliberation (MacLin et al. 2009). Police officers and students

judged date rape suspects who expressed remorse to be more credible, less likely to reoffend, and more amenable to treatment relative to unemotional suspects - though defendant emotion did not always affect verdicts or sentencing (Proeve \& Howells 2006, Wessel et al. 2012). Mock jurors 
award lower damage awards when civil defendants express remorse than when they do not (Bornstein et al. 2002). Problematically, it is difficult for defendants to convey remorse when they do not testify or when they are innocent. Further, there is no sure sign of remorse: Some judges consider hanging one's head to be a sign of respect, while others consider it a sign of disrespect (Bandes 2016, Zhong 2014). Yet, defendants not meeting expectations for remorse is literally a life-and-death matter.

However, defendants expressing emotion is not always beneficial. If a defendant denied committing the crime, mock jurors convicted more when he expressed remorse relative to no remorse (Jehle et al. 2009). Female defendants not only must express remorse but need just the right level. Mock jurors thought female (but not male) defendants were more guilty when they

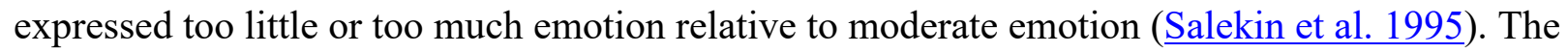
type and timing of emotion are also important. Mock jurors convicted defendants of murder more often when a defendant ( $a$ ) expressed anger (versus remorse or unemotional) during trial (MacLin et al. 2009), (b) claimed he was feeling jealous (versus angry, fearful, or sad) during a heat-of-passion crime ( Spackman et al. 2002b) , and (c) reported allowing himself to dwell on his emotions (Spackman et al. 2002a,b).

\section{Victims}

Contrary to popular belief, children commonly report abuse experiences with no emotion (Goodman et al. 1992, Sayfan et al. 2008), and adult rape victims' behavior ranges from sobbing to exhibiting control and numbness (Burgess \& Holmstrom 1974). Yet, people also hold strong intuitions that victims should react to their trauma with emotion. Emotionality is cited as important in judging the credibility of child victims by prosecutors (Castelli \& Goodman 2014), child protection workers and law enforcement (Boat \& Everson 1988), actual jurors (Myers et al. 1999), and laypeople (egan \& Baker 1998) - as well as in judging adult victims (스tonio \& Arone 2005).

There is robust evidence for the emotional victim effect (EVE) (Ask \& Landstrom 2010, Nitschke et al. 2019, van Doorn \& Koster 2019): Victims gain credibility by expressing negative emotion relative to expressing no emotion or positive emotion (e.g., happiness) — an effect demonstrated among both laypeople and criminal justice professionals (Nitschke et al. 2019), for both physical and sexual assault victims (van Doorn \& Koster 2019), and for both adult and child victims (van Doorn \& Koster 2019). This bolstered credibility of an emotional witness leads to 
more guilty verdicts (Dahl et al. 2007, Golding et al. 2003, Kaufmann et al. 2003) and harsher sentencing recommendations (Nadler \& Rose 2003, Tsoudis \& Smith-Lovin 1998). Similar to defendant emotion (Salekin et al. 1995), at least one study demonstrated the specificity of expectations, such that too little and also too much emotion were less credible than moderate emotion (Golding et al. 2003). However, one study demonstrates the EVE among laypeople but not judges (Wessel et al. 2006), and another suggests that the EVE might not survive jury deliberation (Dahl et al. 2007).

The EVE is explained by more (versus less) emotional victims conforming more with factfinders' expectations (Landström et al. 2015, Lens et al. 2014) and is diminished among factfinders who have weaker emotion expectations for victims (Hackett et al. 2008). These expectations can be shaped by the seriousness of the injury. People expect and react more favorably to victims whose emotion level matches the severity of the crime; high emotion from a victim can backfire if in response to a relatively less serious crime (Lens et al. 2014, $\underline{\text { Rose et al. }}$ 2006). This might explain why victim emotion does not affect credibility in studies involving less serious crimes (Justice \& Smith 2018).

\section{Witnesses}

Thus, there appear to be clear emotion expectations for witnesses who fall into a victim or perpetrator role. What about witnesses who are not the victim or perpetrator? One study demonstrated that eyewitness accounts delivered with more emotion were remembered better than unemotional accounts (Block et al. 2009) but did not assess perceptions of witness credibility or appropriateness. Anecdotal evidence reveals many examples of people being falsely convicted of crimes they witnessed after detectives found their emotion level inappropriate at the scene or on a 911 call (Heath 2009). My collaborators and I have found that laypeople and police officers perceive people who call 911 to report a shooting to be highly suspicious when they express no emotion relative to moderate or high emotion-regardless of whether they are calling about a stranger, parent, or spouse (J.M. Salerno, S.R. Bean, N. Duran $\&$ S. Kassin, manuscript in preparation). Further, in line with stereotypes that women are more emotional than men (Fabes \& Martin 1991), we found some evidence that people might be more suspicious of high emotion from male versus female callers. Favorable reactions to emotional female victims might also explain why people rate female police officers who violate gender roles by expressing aggression and anger by exerting force more favorably than male officers 
who exert force. We found that when a male officer exerted force, people believed it was because he was an aggressive person and trusted him less, whereas they believed that a female officer exerted force because of external danger that she was in and trusted her more (Salerno \&

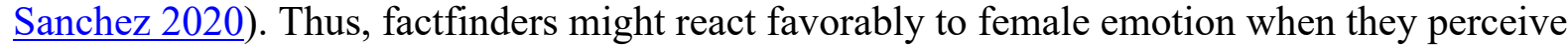
those women to be in the role of a potential victim.

\section{Jurors}

People are far less accepting of female emotion, however, when the women are not in a potential victim role. Inside and outside of the legal context, expressing conviction and emotion is a powerful persuasion tool. Some argue that anger, in particular, evolved as a means to gain influence over others (Van Kleef et al. 2011). Expressing anger leads to opponents making more

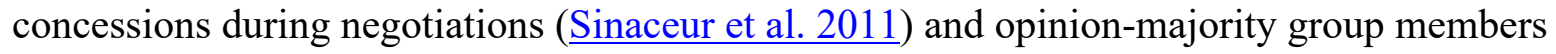
changing their mind and agreeing with an angry minority opinion more often than non-angry minority opinions ( Elfenbein 2012), competence, power (Lerner \& Tiedens 2006), and threat, which motivates people to process one's message more carefully (Calanchini et al. 2016). Thus, expressing anger might be extremely helpful to jurors or attorneys who are trying to persuade others to listen to their arguments. However, this tool is not equally available to everyone. For example, in the workplace, White men gain status and competence from expressing anger, whereas White women lose them (e.g., Brescoll \& Uhlmann 2008).

In contrast to when women are victims and people react favorably toward them being emotional, we found that people infer negative traits about women who express emotion when in the role of a juror. Mock jurors' expressions of anger during deliberation had very different effects on their level of influence over their co-jurors, depending on their gender and race. In tightly controlled experiments, my collaborator and I led mock jurors to believe that they were deliberating online with a holdout juror who disagreed with them and four other jurors. When holdouts with a male name expressed their opinion with anger, relative to the same comments without anger, participants became significantly less confident in their own opinion. In contrast, when holdouts with a female name expressed the same exact opinions with the same statements of anger, participants became significantly more confident in their own opinion (Salerno \& Peter-Hagene 2015). Male holdouts gained influence with anger, and female holdouts lost it. Similarly, holdouts with female or stereotypically African American names lost influence when 
they expressed anger, whereas holdouts with stereotypically White male names did not (Salerno et al. 2019). Interestingly, all angry holdouts were perceived to be similarly emotional in these studies - but participants drew different inferences from that emotion depending on the holdout's gender and race. Being perceived as emotional was selectively used against angry female and Black holdouts, which rendered them less influential. However, people made positive inferences that angry White men were more competent than calm White men, which made angry White men more influential on mock juries (Salerno \& Peter-Hagene 2015, Salerno et al. 2019).

\section{Attorneys}

Other studies have found similar biases against angry female attorneys - despite the fact that they are credentialled by the court and expressing anger on behalf of another, which is more in line with gender stereotypes. Attorneys are often taught that expressing emotion can demonstrate conviction and help them connect with jurors. When male and female attorneys delivered the same closing statement in an angry or calm tone, participants were significantly more likely to want to hire an angry (versus calm) male attorney but significantly less likely to want to hire an angry (versus calm) female attorney (Salerno et al. 2018). Similar to the juror studies, angry male and female attorneys were perceived to be similarly emotional, but people drew positive inferences from anger to justify hiring an angry male attorney, such as him being more convincing and powerful, but drew negative inferences from anger to justify not hiring a female attorney, such as her being more shrill and obnoxious (Salerno et al. 2018). This gender bias against angry women appears to be driven, at least in part, by gender norms. Participants who were more likely to hold traditional gender norms (i.e., reported more benevolent sexism or were more politically conservative or older) favored male attorneys who conformed to gender norms by expressing anger but exhibited backlash against female attorneys who violated gender norms by expressing anger. These biases did not manifest in those who held less traditional gender norms (Salerno \& Phalen 2019b).

\section{Expressed Emotion Summary}

Factfinders have very strong and specific intuitions and expectations for how much emotion and what kind of emotion is appropriate for people to express in legal settings. These expectations depend on many contextual factors, such as the expresser's legal role, gender, and race. Despite the fact that these expectations often run counter to reality, witnesses, defendants, jurors, and 
attorneys all lose credibility when they violate them — with potentially dire lifelong legal consequences. Although emotion is generally expected and desired from defendants, victims, and witnesses of violent crimes, expressing too much can backfire. Reactions to emotion expressed by jurors and attorneys arguing a legal case depend on their gender and race. People draw negative inferences from women's and African Americans' anger, and these groups lose influence when they express anger as a result. Yet, people draw positive inferences from White men's anger, who gain influence as a result of expressing the same anger. Thus, heightened emotions might exacerbate biases against women and African Americans and diminish their influence in the legal system when they are most convicted: when arguing their opinions with emotion.

\section{CONCLUSION}

We deal with our own and others' emotions every day. This familiarity breeds overconfidence that we know our own emotions and their impact, as well as strong intuitions about what to expect from others' emotions and how to read them. However, emotional responses are far more varied and complicated than people realize; emotional cues are not as reliable as we think. It is important to educate legal actors to help them take into account the potentially prejudicial (and often unconscious) impact that intense negative moral emotions can have on legal decisionmaking processes. This is crucial for decisions about how much emotional evidence to admit and in what form. When emotional evidence is unavoidable, the legal system should consider allowing jury instructions or other safeguards to educate factfinders about their own potential biases stemming from their understandable and inevitable emotional responses. In a legal system that relies so heavily on factfinders assessing others' credibility to resolve conflicting stories, we need to make factfinders aware of the dangers of impugning defendants, victims, and witnesses for violating their own expectations for what is appropriate emotion in a given setting - and make them aware of how their own credibility might be impugned when expressing emotion while deliberating about a case.

\section{FUTURE ISSUES}

1. Very little empirical or experimental research investigates the impact of judges' emotions 
on their decision-making processes. Future research should test whether judges are better able to regulate their emotions and prevent their biasing impact on their decision-making processes than laypeople and, if not, what interventions might help them do so. It is also important to develop decision-making aids to help judges weigh the probative and prejudicial impact of evidence in admissibility decisions.

2. Although the legal system puts a lot of faith in deliberation as a debiasing safeguard, no published studies, to my knowledge, have tested the impact of emotionally disturbing evidence before versus after deliberation. Future research should investigate whether deliberation exacerbates or mitigates the impact of jurors' emotions on their verdicts, as well as how emotion manifests in and affects the deliberation process itself.

3. All empirical assessments of factfinders' emotions rely on self-report that occurs either (a) before reviewing the trial evidence, which raises the possibility that jurors are primed to pay attention to emotions or artificially produce reactance, and/or $(b)$ after reviewing trial evidence and making their judgments, which raises the possibility that they do not accurately represent the emotion level before or during their judgments. Researchers should incorporate real-time measures of emotion that do not rely on self-report, such as psychophysiological monitoring.

4. Researchers should investigate how emerging technologies might give rise to novel emotional experiences and how those emotions affect factfinders' judgments. Examples include being put in the first-person perspective of being shot via an officer's body camera and being immersed in Hollywood-level animated or virtual reality reenactments of violent crimes or accidents; the latter is particularly important because it is a demonstrative aid rather than actual evidence - though it might feel that way.

5. Some legal psychological science has investigated the differential impact of different specific emotions with a negative valence (e.g., anger increases reliance on stereotypes while choosing a verdict, but sadness does not; anger and disgust affect legal judgments, while sadness and fear seem to have less of an effect), which is important to continue. However, future research must also integrate more modern theories of emotions, such as Lisa Feldman Barret's Theory of Constructed Emotion. These theories posit that there are no discrete emotion entities, such as anger versus sadness. Instead, people experience general core affect that differs in valence (i.e., positive versus negative) and arousal (i.e., 
high versus low). They argue that people interpret this constantly fluctuating experience of valanced arousal through culturally constructed emotion concepts, and thereby categorize them into mental representations of emotions. In other words, "anger" and "sadness" don't exist as discrete emotions, but are prototypical categories that people have learned to use to subjectively interpret the fluctuations in their affect, based on contextual and cultural factors. For example, if someone experiences a spike in negative and high arousal affect after someone cuts them off in traffic, one person might look at the context and decide they are feeling anger about what the other driver did, while another person might decide they are feeling fear about almost getting into an accident. This conceptualization of emotion might have very different and important implications for how we attempt to regulate factfinders' emotions and interpret legal actors' expressions of emotion, implications that must be tested empirically.

6. Researchers should develop and evaluate ways of presenting probative information in less emotionally disturbing ways, such as 3D images or models of victims' injuries that convey the physics and mechanics of an injury without the vivid gore of photographs and videos.

\section{DISCLOSURE STATEMENT}

The author is not aware of any affiliations, memberships, funding, or financial holdings that might be perceived as affecting the objectivity of this review.

\section{ACKNOLWEDGEMENTS}

I am very grateful to Janice Nadler and Susan Bandes for their thoughtful comments on an earlier draft of this article.

\section{LITERATURE CITED}

Alicke M. 2000. Culpable control and the psychology of blame. Psychol. Bull. 126:556-74 Anderson CA, Shibuya A, Ihori N. 2010. Violent video game effects on aggression, empathy, and prosocial behavior in eastern and western countries: a meta-analytic review. Psychol. Bull. 136:151-73 
Anleu SR, Mack K. 2005. Magistrates' everyday work and emotional labour. J. Law Soc. 32(4):590-614

Antonio ME, Arone NE. 2005. Damned if they do, damned if they don't: jurors' reaction to defendant testimony or silence during a capital trial. Judicature 89:60-66

Archer RL, Foushee HC, Davis MH, Aderman D. 1979. Emotional empathy in a courtroom simulation: a person-situation interaction1. J. Appl. Soc. Pyschol. 9(3):275-91

Ask K, Landstrom S. 2010. Why emotions matter: expectancy violation and affective response mediate the emotional victim effect. Law Hum. Behav. 10:392-401

Ask K, Pina A. 2011. On being angry and punitive: how anger alters perception of criminal intent. Soc. Psychol. Personal. Sci. 2(5):494-99

Bandes S. 1999. When victims seek closure: forgiveness, vengeance and the role of government. Fordham Urb. Law J. 27:1599-606

Bandes SA. 2016. Remorse and criminal justice. Emot. Rev. 8(1):14-19

Bandes SA, Salerno JM. 2014. Emotion, proof, and prejudice: the cognitive science of gruesome photos and victim impact statements. Ariz. State Law J. 54

Bastian B, Denson TF, Haslam N. 2013. The roles of dehumanization and moral outrage in retributive justice. PLOS ONE 8(4):e61842

Block SD, Greenberg SN, Goodman GS. 2009. Remembrance of eyewitness testimony: effects of emotional content, self-relevance, and emotional tone. J. Appl. Soc. Psychol. 39(12):285978

Bloom P. 2006. Against Empathy: The Case for Rational Compassion. New York: Ecco

Boat BW, Everson MD. 1988. Use of anatomical dolls among professionals in sexual abuse evaluations. Child Abuse Neglect. 12(2):171-79

Bodenhausen GV, Sheppard LA, Kramer GP. 1994. Negative affect and social judgment: the differential impact of anger and sadness. Eur. J. Soc. Psychol. 24:45-62

Bond C, Atoum A, Pitre U, Lashley B, Skaggs L, Kirk C. 1993. Fishy-looking liars: deception judgment from expectancy violation. J. Personal. Soc. Psychol. 63:969-77

Bornstein BH, Rung LM, Miller MK. 2002. The effects of defendant remorse on mock juror decisions in a malpractice case. Behav. Sci. Law. 20(4):393-409

Brescoll VL, Uhlmann EL. 2008. Can an angry woman get ahead? Status conferral, gender, and expression of emotion in the workplace. Psychol. Sci. 19(3):268-75 
Bright DA, Goodman-Delahunty J. 2006. Gruesome evidence and emotion: anger, blame, and jury decision-making. Law Hum. Behav. 30(2):183-202

Bright DA, Goodman-Delahunty J. 2011. Mock juror decision making in a civil negligence trial: the impact of gruesome evidence injury severity, and information processing route. Psychiatry Psychol. Law. 18:439-59

Burgess AW, Holmstrom LL. 1974. Rape trauma syndrome. AJP 131(9):981-86

Calanchini J, Moons WG, Mackie DM. 2016. Angry expressions induce extensive processing of persuasive appeals. J. Exp. Soc. Psychol. 64:88-98

Canli T, Zhao Z, Brewer J, Gabrieli JDE, Cahill L. 2000. Event-related activation in the human amygdala associates with later memory for individual emotional experience. J. Neurosci. 20(19):RC99

Carlsmith K, Darley J, Robinson P. 2002. Why do we punish? Deterrence and just deserts as motives for punishment. J. Personal. Soc. Psychol. 83:284-99

Castelli P, Goodman GS. 2014. Children's perceived emotional behavior at disclosure and prosecutors' evaluations. Child Abuse Neglect. 38(9):1521-32

Chamberlain J, Miller MK. 2008. Stress in the courtroom: call for research. Psychiatry Psychol. Law. 15(2):237-50

Chapman H, Anderson A. 2013. Things rank and gross in nature: a review and synthesis of moral disgust. Psychol. Bull. 139(2):300-27

Cline, VB, Croft, RG, \& Courrier, S. 1973. Desensitization of children to television violence. Journal of Personality and Social Psychology. 27(3): 360-365.

Dahl J, Enemo I, Drevland GCB, Wessel E, Eilertsen DE, Magnussen S. 2007. Displayed emotions and witness credibility: a comparison of judgements by individuals and mock juries. Appl. Cognit. Psychol. 21(9):1145-55

Deffenbacher KA, Bornstein BH, Penrod SD, McGorty EK. 2004. A meta-analytic review of the effects of high stress on eyewitness memory. Law Hum. Behav. 28(6):687-706

Devine PG, Forscher PS, Austin AJ, Cox WTL. 2012. Long-term reduction in implicit race bias: a prejudice habit-breaking intervention. J. Exp. Soc. Psychol. 48(6):1267-78

Edwards E, Mottarella K. 2014. Preserving the right to a fair trial: an examination of prejudicial value of visual and auditory evidence. N. Am. J. Psychol. 16:397-414

Edwards K, Bryan TS. 1997. Judgmental biases produced by instructions to disregard: the 
(paradoxical) case of emotional information. Personal. Soc. Psychol. Bull. 23:849-64

Engelken C, Peter-Hagene LC. 2020. Emotion suppression reduces the effect of graphic evidence on disgust and verdicts, but impairs jurors' memory. Presented at the Annual Meeting of Psychology-Law Society, New Orleans, LA

Fabes RA, Martin CL. 1991. Gender and age stereotypes of emotionality. Personal. Soc. Psychol. Bull. 17(5):532-40

Feigenson N. 2016. Jurors' emotions and judgments of legal responsibility and blame: What does the experimental research tell us? Emot. Rev. 8(1):26-31

Feigenson N, Park J. 2006. Emotions and attributions of legal responsibility and blame: a research review. Law Hum. Behav. 30(2):143-61

Finkelstein R, Bastounis M. 2010. The effect of the deliberation process and jurors' prior legal knowledge on the sentence: the role of psychological expertise and crime scene photo. Behav. Sci. Law 28(3):426-41

Forgas J. 1995. Mood and judgment: The Affect Infusion Model (AIM). Psychol. Bull. 117:3966

Fridman J, Barrett LF, Wormwood JB, Quigley KS. 2019. Applying the theory of constructed emotion to police decision making. Front. Psychol. 10:1946

Gable P, Harmon-Jones E. 2010. The motivational dimensional model of affect: implications for breadth of attention, memory, and cognitive categorisation. Cogn. Emot. 24(2): 322-37.

Gazzo Castañeda LE, Knauff M. 2016. Defeasible reasoning with legal conditionals. Mem. Cogn. 44(3):499-517

Georges LC, Wiener RL, Keller SR. 2013. The angry juror: sentencing decisions in first-degree murder. Appl. Cognit. Psychol. 27(2):156-66

Giner-Sorolla R. 2012. Judging passions: moral emotions in persons and groups. Taylor \& Francis Group.

Goldberg JH, Lerner JS, Tetlock PE. 1999. Rage and reason: the psychology of the intuitive prosecutor. Eur. J. Soc. Psychol. 29:781-95

Golding JM, Fryman HM, Marsil DF, Yozwiak JA. 2003. Big girls don't cry: the effect of child witness demeanor on juror decisions in a child sexual abuse trial. Child Abuse Neglect. 27(11):1311-21

Goodman GS, Taub EP, Jones DPH, England P, Port LK, et al. 1992. Testifying in criminal 
court: emotional effects on child sexual assault victims. Monogr. Soc. Res. Child Dev. 57(5)

Grady RH, Reiser L, Garcia RJ, Koeu C, Scurich N. 2018. Impact of gruesome photographic evidence on legal decisions: a meta-analysis. Psychiatr. Psychol. Law 25(4):503-21

Greene, E, Koehring, H, \& Quiat, M. 1998. Victim impact evidence in capital cases: Does the victim's character matter? Journal of Applied Social Psychology 28(2): 145-156.

Gross JJ. 1998. The emerging field of emotion regulation: an integrative review. Rev. Gen. Psychol. 2:271-99

Gross JJ, Levenson RW. 1993. Emotional suppression: physiology, self-report, and expressive behavior. J. Personal. Soc. Psychol. 64:970-86

Gross JJ, Thompson RA. 2007. Emotion regulation: conceptual foundations. In Handbook of Emotion Regulation, ed. JJ Gross, pp. 3-24. New York: Guilford

Hackett L, Day A, Mohr P. 2008. Expectancy violation and perceptions of rape victim credibility. Leg. Criminol. Psychol. 13(2):323-34

Haegerich TM, Bottoms BL. 2000. Empathy and jurors' decisions in patricide trials involving child sexual assault allegations. Law Hum. Behav. 24:421-48

Haidt, J. 2002. The moral emotions. In Handbook of Affective Sciences, eds. RJ Davidson, KR Scherer, \& HH Goldsmith (Eds), pp. 582-870. Oxford University Press.

Haney C, Sontag L, Costanzo S. 1994. Deciding to take a life: capital juries, sentencing instructions, and the jurisprudence of death. J. Soc. Issues 50(2):149-76

Hareli S, Hess U. 2010. What emotional reactions can tell us about the nature of others: an appraisal perspective on person perception. Cogn. Emot. 24(1):128-40

Heath WP. 2009. Arresting and convicting the innocent: the potential role of an "inappropriate" emotional display in the accused. Behav. Sci. Law 27(3):313-32

Heerdink MW, van Kleef GA, Homan AC, Fischer AH. 2013. On the social influence of emotions in groups: interpersonal effects of anger and happiness on conformity versus deviance. J. Personal. Soc. Psychol. 105(2):262-84

Horberg EJ, Keltner D, Oveis C, Cohen AB. 2009. Disgust and the moralization of purity. $J$. Personal. Soc. Psychol. 97:963-76

Jaffe PG, Crooks CV, Dunford-Jackson BL, Town JM. 2003. Vicarious trauma in judges: the personal challenge of dispensing justice. Juv. Fam. Court J. 54(4):1-9

Jehle A, Miller MK, Kemmelmeier M. 2009. The influence of accounts and remorse on mock 
jurors' judgments of offenders. Law Hum. Behav. 33(5):393-404

Jones TM, Bottoms BL, Stevenson MC. 2020. Child victim empathy mediates the influence of jurors' sexual abuse experiences on child sexual abuse case judgments: meta-analyses. Psychol. Public Policy Law 26(3):312-32

Justice LV, Smith HMJ. 2018. Memory judgements: the contribution of detail and emotion to assessments of believability and reliability. Memory 26(10):1402-15

Kaplan RL, Van Damme I, Levine LJ, Loftus EF. 2016. Emotion and false memory. Emot. Rev. $8(1): 8-13$

Kassin SM, Garfield DA. 1991. Blood and guts: general and trial-specific effects of videotaped crime scenes on mock jurors. J. Appl. Soc. Psychol. 21(18):1459-72

Kaufmann G, Drevland GCB, Wessel E, Overskeid G, Magnussen S. 2003. The importance of being earnest: displayed emotions and witness credibility. Appl. Cognit. Psychol. 17(1):2134

Keltner D, Ellsworth PC, Edwards K. 1993. Beyond simple pessimism: effects of sadness and anger on social perception. J. Personal. Soc. Psychol. 64:740-52

Keltner D, Haidt J. 1999. Social functions of emotions at four levels of analysis. Cogn. Emot. 13:505-21

Koenigs M, Young L, Adolphs R, Tranel D, Cushman F, et al. 2007. Damage to the prefrontal cortex increases utilitarian moral judgements. Nature 446(7138):908-11

Landström S, Ask K, Sommar C, Willén R. 2015. Children's testimony and the emotional victim effect. Leg. Crim. Psychol. 20(2):365-83

Laukka P, Elfenbein HA. 2012. Emotion appraisal dimensions can be inferred from vocal expressions. Soc. Psychol. Personal. Sci. 3(5):529-36

Lens KME, van Doorn J, Pemberton A, Bogaerts S. 2014. You shouldn't feel that way! Extending the emotional victim effect through the mediating role of expectancy violation. Psychol. Crime Law 20(4):326-38

Lerner JS, Goldberg JH, Tetlock PE. 1998. Sober second thought: the effects of accountability, anger, and authoritarianism on attributions of responsibility. Personal. Soc. Psychol. Bull. 24(6):563-74

Lerner JS, Tiedens LZ. 2006. Portrait of the angry decision maker: how appraisal tendencies shape anger's influence on cognition. J. Behav. Decis. Making 19(2):115-37 
Loewenstein G, Small DA. 2007. The Scarecrow and the Tin Man: the vicissitudes of human sympathy and caring. Rev. Gen. Psychol. 11(2):112-26

Lonergan M, Leclerc M-È, Descamps M, Pigeon S, Brunet A. 2016. Prevalence and severity of trauma- and stressor-related symptoms among jurors: a review. J. Crim. Justice 47:51-61

Lotz S, Okimoto TG, Schlösser T, Fetchenhauer D. 2011. Punitive versus compensatory reactions to injustice: emotional antecedents to third-party interventions. J. Exp. Soc. Psychol. 47(2):477-80

MacLin MK, Downs C, MacLin OH, Caspers HM. 2009. The effect of defendant facial expression on mock juror decision-making: the power of remorse. N. Am. J. Psychol. $11: 323-32$

Maroney TA. 2011. The persistent cultural script of judicial dispassion. Calif. Law Rev. 99(2):629-81

Maroney TA. 2012. Angry judges. Vanderbilt Law Rev. 65:1207-86

Maroney TA, Gross JJ. 2014. The ideal of the dispassionate judge: an emotion regulation perspective. Emot. Rev. 6(2):142-51

Matsuo K, Itoh Y. 2017. The effects of limiting instructions about emotional evidence depend on need for cognition. Psychiatry Psychol. Law 24(4):516-29

McCracken EW, Stevenson MC. 2017. Rape perpetrator gender shapes liability judgments: implications for disgust and moral outrage. Transl. Issues Psychol. Sci. 3(2):153-66

Myers JEB, Redlich AD, Goodman GS, Prizmich LP, Imwinkelried E. 1999. Jurors' perceptions of hearsay in child sexual abuse cases. Psychol. Public Policy Law 5(2):388-419

Nadler J. 2012. Blaming as a social process: the influence of character and moral emotion on blame. Law Contemp. Probl. 75:1-31

Nadler J, McDonnell M-HM. 2012. Moral character, motive, and the psychology of blame. Cornell Law Rev. 97:255-304

Nadler J, Rose MR. 2003. Victim impact testimony and the psychology of punishment. Cornell Law Rev. 88:419-56

Nitschke FT, McKimmie BM, Vanman EJ. 2019. A meta-analysis of the emotional victim effect for female adult rape complainants: Does complainant distress influence credibility? Psychol. Bull. 145(10):953-79

Nuñez N, Schweitzer K, Chai CA, Myers B. 2015. Negative emotions felt during trial: the effect 
of fear, anger, and sadness on juror decision making. Appl. Cognit. Psychol. 29(2):200-9

Ochsner, KN, \& Phelps, E. 2007. Emerging perspectives on emotion-cognition interactions. Trends in Cognitive Sciences 11(8): 317-318.

Okimoto TG, Brescoll VL. 2010. The price of power: power seeking and backlash against female politicians. Personal. Soc. Psychol. Bull. 36(7):923-36

Oliver E, Griffitt W. 1976. Emotional arousal and "objective” judgment. Bull. Psychon. Soc. 8(5):399-400

Palmer EA. 2005. Variables influencing the vicarious trauma of jurors in criminal cases. PsyD thesis, Univ. North. Colo., Greeley, CO

Paternoster R, Deise J. 2011. A heavy thumb on the scale: the effect of victim impact evidence on capital decision making. Criminology 49(1):129-61

Payne JD, Nadel L, Britton WB, Jacobs WJ. 2004. The biopsychology of trauma and memory. In Memory and Emotion, pp. 76-128. New York: Oxford Univ. Press

Peter-Hagene LC, Bottoms BL. 2017. Attitudes, anger, and nullification instructions influence jurors' verdicts in euthanasia cases. Psychol. Crime Law 23(10):983-1009

Phalen HJ, Salerno JM, Peter-Hagene CL. 2020. Emotional evidence in court. In Research Handbook on Law and Emotion, eds. SA Bandes, JL Madeira, LF Niezer, KD Temple, E White, pp. 288-311. Res. Handb. Legal Theory. Cheltenham, UK: Edward Elgar

Proeve MJ, Howells K. 2006. Effects of remorse and shame and criminal justice experience on judgements about a sex offender. Psychol. Crime Law 12(2):145-61

Regan PC, Baker SJ. 1998. The impact of child witness demeanor on perceived credibility and trial outcome in sexual abuse cases. J. Fam. Violence 13:187-95

Reisberg D, Heuer F. 2004. Memory for emotional events. In Memory and Emotion, eds. Reisberg \& P Hertel, pp. 3-41. New York: Oxford Univ. Press.

Reisberg D, Heuer F. 2007. The influence of emotion on memory in forensic settings. In Handbook of Eyewitness Psychology, Vol. 1. Memory for Events, ed. MP Toglia, JD Read, DF Ross, RCL Lindsay, pp. 81-116. Mahwah, NJ: Lawrence Erlbaum Assoc.

Robertson N, Davies G, Nettleingham A. 2009. Vicarious traumatisation as a consequence of jury service. Howard J. Crim. Justice 48(1):1-12

Rose MR, Nadler J, Clark J. 2006. Appropriately upset? Emotion norms and perceptions of crime victims. Law Hum. Behav. 30: 203-19. 
Ruva CL, Guenther CC, Yarbrough A. 2011. Positive and negative pretrial publicity: the roles of impression formation, emotion, and predecisional distortion. Crim. Justice Behav. 38(5):51134

Salekin RT, Ogloff JRP, McFarland C, Rogers R. 1995. Influencing jurors' perceptions of guilt: expression of emotionality during testimony. Behav. Sci. Law 13(2):293-305

Salerno JM. 2017. Seeing red: disgust reactions to gruesome photographs in color (but not in black and white) increase convictions. Psychol. Public Policy Law 23(3):336-50

Salerno JM, Bean SR, Duran N, Kassin S. Manuscript in preparation. Generating suspicion in 911 calls.

Salerno JM, Bottoms BL. 2009. Emotional evidence and jurors' judgments: the promise of neuroscience for informing psychology and law. Behav. Sci. Law 27(2):273-96

Salerno JM, Murphy MC, Bottoms BL. 2014. Give the kid a break—but only if he's straight: retributive motives drive biases against gay youth in ambiguous punishment contexts. Psychol. Public Policy Law 20(4):398-410

Salerno JM, Nadler J, Bailey B. Manuscript in preparation. The impact of gruesome photographs of White versus Black victims on mock jurors' emotions and verdicts.

Salerno JM, Najdowski C, Bottoms B, Harrington E, Kemner G, Dave R. 2015. Excusing murder? Conservative jurors' acceptance of the gay-panic defense. Psychol. Public Policy Law 21:24-34

Salerno JM, Peter-Hagene LC. 2013. The interactive effect of anger and disgust on moral outrage and judgments. Psychol. Sci. 24(10):2069-78

Salerno JM, Peter-Hagene LC. 2015. One angry woman: Anger expression increases influence for men, but decreases influence for women, during group deliberation. Law Hum. Behav. 39(6):581-92

Salerno JM, Peter-Hagene LC, Jay ACV. 2019. Women and African Americans are less influential when they express anger during group decision making. Group Process. Intergroup Relat. 22(1):57-79

Salerno JM, Phalen HJ. 2019a. The impact of gruesome photographs on mock jurors' emotional responses and decision making in a civil case. DePaul Law Rev. 69:633-56

Salerno JM, Phalen HJ. 2019b. Traditional gender roles and backlash against female attorneys expressing anger in court. J. Empir. Leg. Stud. 16(4):909-32 
Salerno JM, Phalen HJ, Nadler J, Schweitzer NJ, Bandes SA. Manuscript in preparation. The impact of gruesome photographs and jury instructions on deliberating jurors' emotions and verdicts.

Salerno JM, Phalen HJ, Reyes RN, Schweitzer NJ. 2018. Closing with emotion: the differential impact of male versus female attorneys expressing anger in court. Law Hum. Behav. 42(4):385-401

Salerno JM, Sanchez J. 2020. Subjective interpretation of “objective” video evidence: perceptions of male versus female police officers' use-of-force. Law Hum. Behav. 44(2):97112

Sayfan L, Mitchell EB, Goodman GS, Eisen ML, Qin J. 2008. Children's expressed emotions when disclosing maltreatment. Child Abuse Negl. 32(11):1026-36

Schein C, Ritter RS, Gray K. 2016. Harm mediates the disgust-immorality link. Emotion $16(6): 862-76$

Schnall S, Haidt J, Clore GL, Jordan AH. 2008. Disgust as embodied moral judgment. Personal. Soc. Psychol. Bull. 34(8):1096-109

Schwarz N, Clore G. 1983. Mood, misattribution, and judgments of well-being: informative and directive functions of affective states. J. Personal. Soc. Psychol. 45:513-23

Schweitzer K, Nuñez N. 2018. What evidence matters to jurors? The prevalence and importance of different homicide trial evidence to mock jurors. Psychiatry Psychol. Law 25(3):437-51

Semmler C, Brewer N. 2002. Effects of mood and emotion on juror processing and judgments. Behav. Sci. Law. 20(4):423-36

Shuman DW, Hamilton JA, Daley CE. 1994. The health effects of jury service. Law Psychol. Rev. 18:267-307

Simon D, Stenstrom D, Read S. 2015. The coherence effect: blending cold and hot cognitions. $J$. Personal. Soc. Psychol. 109(3):369-94

Sinaceur M, Van Kleef GA, Neale MA, Adam H, Haag C. 2011. Hot or cold: Is communicating anger or threats more effective in negotiation? J. Appl. Psychol. 96(5):1018-32

Slovic P. 2010. The Feeling of Risk: New Perspectives on Risk Perception. Abingdon, UK: Routledge

Smith C, Ellsworth P. 1985. Patterns of cognitive appraisal in emotion. J. Personal. Soc. Psychol. 48:813-38 
Spackman MP, Belcher JC, Calapp JW, Taylor A. 2002a. An analysis of the effects of subjective and objective instruction forms on mock-juries' murder/manslaughter distinctions. Law Hum. Behav. 26(6):605-23

Spackman MP, Belcher JC, Hansen AS. 2002b. Effects of perceived emotional intensity on mock jurors' murder/manslaughter distinctions. J. Appl. Biobehav. Res. 7(2):87-113

Sundby SE. 1998. The capital jury and absolution: the intersection of trial strategy, remorse, and the death penalty. Cornell Law Rev. 83:1557-98

Tallon JA, Daftary-Kapur T, Penrod S. 2015. Defendant remorse and publicity in capital trials: Is seeing truly believing? Crim. Justice Behav. 42(12):1282-302

Tiedens LZ, Linton S. 2001. Judgment under emotional certainty and uncertainty: the effects of specifics emotions on information processing. J. Personal. Soc. Psychol. 81:973-88

Tsoudis O, Smith-Lovin L. 1998. How bad was it? The effects of victim and perpetrator emotion on responses to criminal court vignettes. Soc. Forces 77:695-722

Van Damme I, Smets K. 2014. The power of emotion versus the power of suggestion: memory for emotional events in the misinformation paradigm. Emotion 14(2):310-20

van Doorn J, Koster NN. 2019. Emotional victims and the impact on credibility: a systematic review. Aggress. Violent Behav. 47:74-89

Van Kleef GA. 2009. How emotions regulate social life: the Emotions as Social Information (EASI) model. Curr. Dir. Psychol. Sci. 18(3):184-88

Van Kleef GA, Van Doorn EA, Heerdink MW, Koning LF. 2011. Emotion is for influence. Eur. Rev. Soc. Psychol. 22(1):114-63

Ward BH. 2006. Sentencing without remorse. Loyola Univ. Chicago Law J. 38:131-67

Warner LR, Shields SA. 2009. Judgements of others' emotional appropriateness are multidimensional. Cogn. Emot. 23:876-88

Wegner DM. 2009. How to think, say, or do precisely the worst thing for any occasion. Science $325: 48-50$

Wessel E, Drevland GCB, Eilertsen DE, Magnussen S. 2006. Credibility of the emotional witness: a study of ratings by court judges. Law Hum. Behav. 30(2):221-30

Wessel EM, Bollingmo GC, Sønsteby C, Nielsen LM, Eliersten DE, Magnussen S. 2012. The emotional witness effect: story content, emotional valence and credibility of a male suspect. Psychol. Crime Law 18(5):417-30 
Whalen DH, Blanchard FA. 1982. Effects of photographic evidence on mock juror judgment. $J$. Appl. Soc. Psychol. 12:30-41

Wheatley T, Haidt J. 2005. Hypnotic disgust makes moral judgments more severe. Psychol. Sci. 16(10):780-84

Yzerbyt V, Dumont M, Wigboldus D, Gordijn E. 2003. I feel for us: the impact of categorization and identification on emotions and action tendencies. Br. J. Soc. Psychol. 42(4):533-49

Zhong R. 2014. So you're sorry? The role of remorse in criminal law. J. Am. Acad. Psychiatry Law 42:39-48 